\title{
車両の交差に必要なリニア信号機の最小構成*
}

\author{
犬塚 康介 ${ }^{\dagger} \cdot$ 東＼cjkstart俊一 ${ }^{\dagger} \cdot 丸$ 田 一郎
}

\section{Minimum Implementation of Linear Traffic Lights for One-way Intersections*}

\author{
Kosuke Inuzuka $^{\dagger}$, Shun-ichi Azuma ${ }^{\dagger}$, Ichiro Maruta ${ }^{\ddagger}$, Ryo ArIIzumi $^{\dagger}$ and Toru Asai ${ }^{\dagger}$
}

\begin{abstract}
Recent years, a new type of traffic lights, called the linear traffic lights, has been proposed. The linear traffic lights, which are placed at an intersection, monitor the traffic status of the crossing roads and control the traffic flow around the intersection. This paper considers the minimum configuration of the linear traffic lights to guarantee non-stopping crossing without collision at the intersection of one-way roads.
\end{abstract}

\section{1.はじめに}

現在，車両の交通流は交通信号機によって制御されて いる．交通信号機は複数の車線の通行権を一定時間ごと に切り換えることで交差点の交通処理を行っているが, 停止の際の待ち時間による時間的損失が少なくない $[1]$. そこで, 近年発展を続けている ICT 技術 [2] を用いて, 従来のものに比べてより効率的な交通を実現させること が考えられている [3-5].

そのための一つの方法として近年,「リニア信号機」と いう新たな信号機が提案されている $[1]$. リニア信号機と は，Fig. 1のように光源が直線状に並べられたリニアラ イトとよばれる装置と, 近接センサが直線状に並べられ たリニアセンサとよばれる装置で構成され，それらを適 切に運用することで車両の停止時間を極力減らし, 円滑 な交通流を実現することを目的としている.

先行研究 [1] では，すべての車線にリニア信号機を配 置することで, 可能な限り車両を停止させずに車両の交 差が可能であることを明らかにしている。しかし，リニ ア信号機をすべての車線に配置する必要があるのか, と いう点に関しては疑問が残っていた。 もしすべての車線

\footnotetext{
* 原稿受付 2019 年 2 月 22 日

$\dagger$ 名古屋大学 大学院 工学研究科 Graduate School of Engineering, Nagoya University; Furo-cho, Chikusa ward, Nagoya city, Aichi 464-8603, JAPAN

¥ 京都大学 大学院 工学研究科 Graduate School of Engineering, Kyoto University; Kyoto daigaku-katsura, Nishikyo ward, Kyoto city, Kyoto 615-8540, JAPAN Key Words: linear traffic lights, multi-agent system.
}

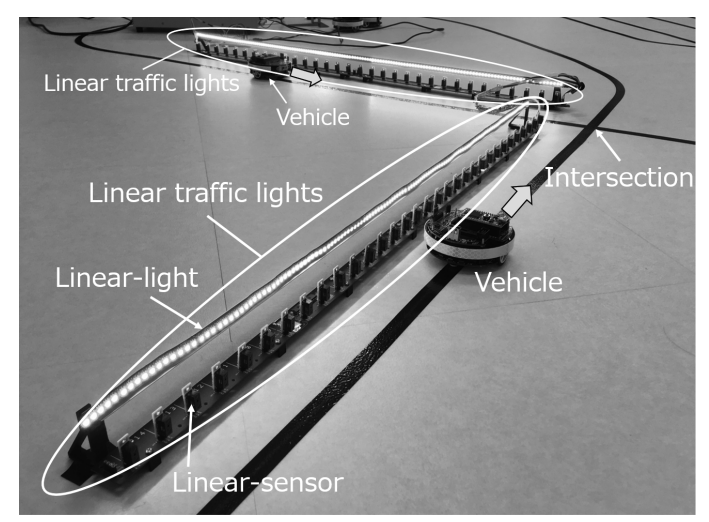

Fig. 1 Linear traffic lights

にリニア信号機を配置しなくともリニア信号機に期待す る上述の目的が達成できるのであれば，リニア信号機の 設置にかかる費用を削減できる。また，リニア信号機が 故障した際にも円滑な交通が望まれるが，どの程度故障 してもよいのか，ということを明らかにしておくことも 重要である.

そこで，本論文では，車両を停止させない交差点を実 現させるために必要なリニア信号機の最小数とその配置 を明らかにすることを目的とする。これに対し，本論文 では， $n$ 本の一方通行路が交わる交差点に対しては, リ ニア信号機を構成するリニアライトとリニアセンサがそ れぞれ $(n-1)$ 個以上必要であり，また，それらは，リ ニアライトとリニアセンサがいずれも備えられない車線 が存在しないように配置することが必要十分条件である ことを示した。 
本論文は以下のように構成される，第 2 章では本論文 で考える交通システムのモデルを与える。第 $\mathbf{3}$ 章では上 述した最小のリニアライトとリニアセンサの数とその配 置を明らかにし，第 4 章でその証明を行う。そして，第 5 章では本論文のまとめを述べる.

記法: $\mathbf{R}$ で実数全体の集合, $\mathbf{R}_{+}$で正の実数全体の集 合を表す.

また, $n$ 個のスカラ変数 $x_{1}, x_{2}, \ldots, x_{n}$ と集合 $\mathbf{I}=$ $\left\{i_{1}, i_{2}, \ldots, i_{m}\right\} \subseteq\{1,2, \ldots, n\}$ に対して,$\quad\left[x_{i}\right]_{i \in \mathbf{I}}$ でベク トル $\left[x_{i_{1}} x_{i_{2}} \cdots x_{i_{m}}\right]$ を表す.ただし, $i_{1}<i_{2}<\cdots<i_{m}$ とする。

また, ベクトル $\left[\begin{array}{llll}x_{1} & x_{2} & \cdots & x_{n}\end{array}\right] \in \mathbf{R}^{1 \times n}$ に対し，関数 $\operatorname{prio}\left(\left[x_{1} x_{2} \cdots x_{n}\right]\right)$ は, $x_{1} x_{2} \cdots x_{n}$ のうち, 非正の ものの中で最も值が大きいものの要素番号を出力する. ただし，それが一意に定まらない場合は，候補の中から 最も小さいものを表す。また， $x_{1} x_{2} \cdots x_{n}$ のうち，非 正のものが存在しない場合は，0を出力する．たとえば, $\operatorname{prio}([1-0.5-3-0.5])=2, \operatorname{prio}\left(\left[\begin{array}{lll}1 & 2 & 5\end{array}\right]\right)=0$ である.

\section{2.リニア信号機が備えられた交通システム}

\section{1 リニア信号機}

リニア信号機とは，文献 [1] で提案された，車両を可 能な限り停止させずに安全に交差点を通行させることを 目的とした交通信号機である。これはFig. 1のようにリ ニアライトとリニアセンサとよばれる装置によって構成 されており，基本的にはこれらの組がひとつずつ各車線 に配置される。

リニアセンサは，複数の近接センサを車線に沿って一 列に並べたものであり，その車線においてどの位置に車 両が存在するかの情報を取得する.

一方，リニアライトは，複数の光源を車線に沿って一 列に並べたものであり，その車線の車両の位置と他の車 線の交通状況の情報をリニアセンサから取得し，その情 報をもとに車両への指令值を光の強さとして車両に送る. 車両には光の強さを測るセンサ（受光素子）が取り付け られており，その值をもとに速度を決定する。

リニア信号機を用いた交通流制御の基本的な考え方を 示す．たとえば，Fig. 2 のように，2 本の一方通行の車 線にそれぞれ 1 台ずつ車両が走行する場合を考える。も し，2台の車両が交差点から同じ距離に位置し, 同じ速 度で交差点に進入したとすると，2台の車両は交差点で 衝突することになる。そこで，このような状況をリニア センサで検出し，リニアライトから片方の車両に対して 減速もしくは加速指令を送る，その結果， 2 台の車両の 交差点への到着時刻に差が生まれ，停止しなくとも交差 点で衝突することなく通過することができる.

\section{2 モデル化}

Fig. 3 のように $n$ 本の一方通行の車線が一点で交わる 交差点において, 各車線に 1 台ずつ車両が存在する状況 を考える。

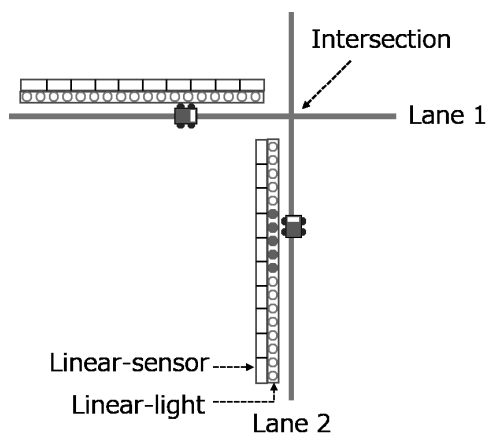

Fig. 2 2-lane intersection with linear traffic lights

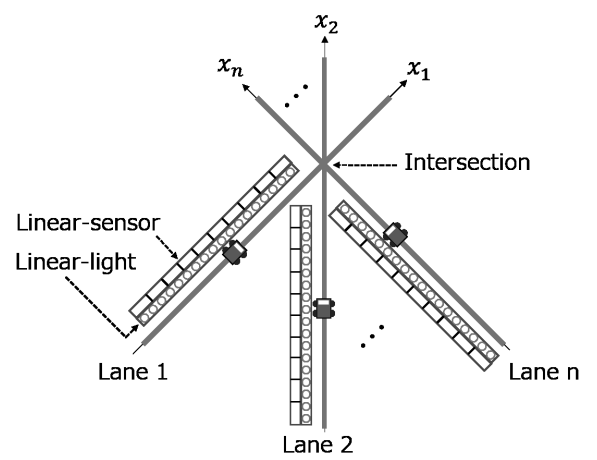

Fig. $3 n$-lane intersection with linear traffic lights

実機においては,リニアライトに備わった光源は有限 個であるため, ひとつの光源の照射する範囲では同じ值 の入力しか与えられないが, ここでは, 任意の位置（実 数值) で別々の入力を与えられると仮定する。また，リ ニアセンサに備わった近接センサも有限個であるため, 実機では量子化された位置情報しか取得できないが，こ こでは，実数值の位置情報が取得できると仮定する.

$n$ 本の車線に $1,2, \ldots, n$ のインデックスを割り当て，そ の集合を $\mathbf{I}=\{1,2, \ldots, n\}$ と表記する。また，車線 $i に$ 存在する車両を車両 $i$ とよぶ. 車両 $i$ の車線 $i$ での位置 を表すために，車線 $i$ の進行方向に沿って座標軸 $x_{i}$ を 導入し，交差点の位置を $x_{i}=0$ とする。そして，時刻 $t$ における車両 $i$ の位置を $x_{i}(t)$ と表す。リニア信号機 は, 各車線の交差点を起点として負方向へ向かう半直線 上，すなわち $x_{i} \leq 0$ の区間に配置されているものとす る。ここで, $x_{i}$ は座標軸を表し, $x_{i}(t)$ は座標軸上の車 両の位置を表すことに注意する。また，車線 $i$ 上のリニ アライトとリニアセンサをそれぞれ記号 $L_{i}, S_{i}$ で記す。 本交通システムのブロック線図は Fig. 4 のように与え られる。

この図において，車両 $i$ のダイナミクスは以下のよj に積分系で与えられるものとする.

$$
\dot{x}_{i}(t)=u_{i}(t)
$$

ここで, $x_{i}(t) \in \mathbf{R}$ は上述の通り時刻 $t$ における車両 $i$ の位置であり，初期時刻における位置を $x_{0 i} \in \mathbf{R}$ とする. 


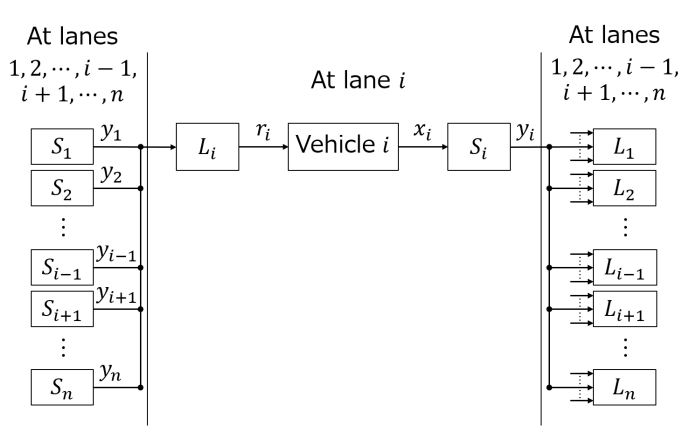

Fig. 4 Block diagram

すなわち, $x_{i}(0)=x_{0 i}$ である。また, $u_{i}(t) \in \mathbf{R}_{+}$は車 両 $i$ の制御入力であり, (一方通行路であるので) 正の值 をとると仮定する.

一方, 車線 $i$ に備えられたリニアセンサ $S_{i}$ とリニア ライト $L_{i}$ はそれぞれ以下のように表される.

$$
\begin{gathered}
S_{i}: y_{i}(t)= \begin{cases}x_{i}(t) & \text { if } x_{i}(t) \leq 0 \\
\infty & \text { otherwise }\end{cases} \\
L_{i}: r_{i}\left(t, x_{i}\right)=g\left(x_{i},\left[y_{j}(t)\right]_{j \in \mathbf{I} \backslash\{i\}}\right)
\end{gathered}
$$

ここで, $y_{i}(t) \in \mathbf{R} \cup\{\infty\}$ は $S_{i}$ の出力であり, 車両 $i$ が リニアセンサが設置された位置 $\left(x_{i} \leq 0\right)$ に存在する場合 は位置 $x_{i}(t)$ と等しく, それ以外の場合は無限大となる. また, $g$ はリニアライトの制御アルゴリズムであり，他 の車線に備えられたリニアセンサ $S_{j}(j \in \mathbf{I} \backslash\{i\})$ から の情報 $y_{j}(t)$ に応じた指令值 $r_{i}\left(t, x_{i}\right)$ を出力する。 ここ で, $r_{i}\left(t, x_{i}\right)$ は時刻 $t$ において,リニアライトにおける 位置 $x_{i}$ に存在する光源の出力を表す.

車両 $i$ の制御器は, 現在の位置 $x_{i}(t)$ において指令値 $r_{i}\left(t, x_{i}(t)\right)$ を受け取り, 制御入力 $u_{i}(t)$ を決定するもの であり, 以下のように与えられる。

$$
u_{i}(t)= \begin{cases}f_{1}\left(r_{i}\left(t, x_{i}(t)\right)\right) & \text { if } x_{i}(t) \leq 0 \\ f_{2}(t) & \text { otherwise }\end{cases}
$$

ここで, $f_{1}:(\mathbf{R} \cup\{\infty\}) \rightarrow \mathbf{R}_{+}, f_{2}: \mathbf{R} \rightarrow \mathbf{R}_{+}$は車両の制 御アルゴリズムに相当する。ここでは，すべての車線に リニアライトとリニアセンサが設置された状況を考えて いるため, 制御入力は (4) 式のように記されるが, リニ アライトが設置されていない場合は， $f_{2}$ だけでモデル化 される。これについては (6) 式として後ほど示す.

また，車両の制御アルゴリズム $f_{1}, f_{2}$ とリニアライ トの制御アルゴリズム $g$ は車線と車両のインデックス $i$ に応じて別々のものが与えられるような問題設定も考元 られるが，本論文ではスケーラビリティの観点から $i に$ 関わらずすべて同じ，すなわち， $f_{1}, f_{2}$ と $g$ に添字 $i$ が 付かないと仮定する.

\section{3. リニア信号機の最小数と配置}

本論文では, Fig. 3 のシステムにおいて，いくつかの リニアライトとリニアセンサが設置されていない状況を
考える，このとき， $n$ 台の車両が交差点の手前に存在す る, すなわち $x_{0 i}<0(i=1,2, \ldots, n)$ の条件のもとで, 車 両同士が衝突せずに交差点を通行するためにはいくつ以 上のリニアライトとリニアセンサが設置され，そして， 設置されているものがどのように配置されていればよい のだろうか. 以下ではこれについて考えていく.

まず,「交差点の通行」と「車両同士の衝突」をそれぞ れ以下のように定義する.

【定義 1】車両 $i$ が交差点を通行するとは，任意の 時刻 $t \in[\tau, \infty)$ で,

$$
x_{i}(t)>0
$$

となるような $\tau \in(0, \infty)$ が存在することである.

【定義 2】車両同士が交差点で衝突するとは,

$$
x_{i}(t)=x_{j}(t)=0
$$

を満たす時刻 $t \in(0, \infty)$ と車両の組 $(i, j) \in \mathbf{I} \times(\mathbf{I} \backslash\{i\})$ が存在することである.

また，リニアライトは設置されているすべてのリニア センサからの情報を取得し車両への指令值を決定できる とする. すなわち, $\mathbf{I}_{s} \subseteq\{1,2, \ldots, n\}$ をリニアセンサが設 置されている車線のインデックス集合とすると, この場 合の $L_{i}$ は

$$
L_{i}: r_{i}\left(t, x_{i}\right)=g\left(x_{i},\left[y_{j}(t)\right]_{j \in \mathbf{I}_{\mathbf{s}} \backslash\{i\}}\right)
$$

と与えられる。

さらに, $\mathbf{I}_{l} \subseteq\{1,2, \ldots, n\}$ をリニアライトが設置されて いる車線， $\mathbf{I}_{n l} \subseteq\{1,2, \ldots, n\}$ をリニアライトが設置され ていない車線のインデックス集合とする。このとき，任 意の時刻 $t \in[0, \infty)$ における車両 $i \in \mathbf{I}_{l}$ の制御入力 $u_{i}(t)$ は (4) 式のように与えられるが, 車両 $i \in \mathbf{I}_{n l}$ の制御入力 $u_{i}(t)$ は

$$
u_{i}(t)=f_{2}(t)
$$

と与えられる

このとき,リニア信号機の最小数と配置についてつぎ の結果が得られる.

【定理 1】 Fig. 3のシステムを考える.このとき, 任 意の初期位置 $x_{0 i} \in(-\infty, 0)(i=1,2, \ldots, n)$ に対し, 各 車両が非零の速度を保ったまま他の車両と衝突せずに交 差点を通行するための車両の制御アルゴリズム $f_{1}, f_{2}$ と リニアライトの制御アルゴリズム $g$ が存在するための必 要十分条件は以下の二つが成立することである.

(a) リニアライトとリニアセンサの総数がそれぞれ $(n-1)$ 以上である.

(b) おの扔のの車線において, 少なくともリニアライト とリニアセンサのいずれか一つが設置されている.

定理 1 の直感的な解釈は以下の通りである. (a) と (b) のいずれかが満たされない場合は以下の三つが考えら 
れる。
（A）リニアライトが設置されていない車線が二つ
存在する.
（B）リニアセンサが設置されていない車線が二つ（以上） 存在する.
(C) リニアライトとリニアセンサがともに設置されてい ない車線が一つ（以上）存在する。

(A) の場合，まったく制御できない独立な 2 台の車両が 存在するため，ある初期位置に対しては，その車両同士 の衝突が生じる。(B) の場合，すべての車両がリニアラ イトで制御できる可能性があるが，2台の車両の位置が 未知となってしまうため，仮にリニアライトで制御でき たとしても，ある初期位置に対しては，その車両同士の 衝突が生じる。(C) の場合, その車線の車両の位置情報 が他の車両に伝達されることはなく，また，その車両を 制御することができない。したがって，その車両と他の 車線の車両とで, ある初期位置に対しては衝突が生じる. これら三つの場合以外は上述のようなことが発生しない のですべての車両は衝突することなく交差点を通行する.

$n=3$ の場合の例を Fig. 5 に示す. (i) はすべての車 線のリニアライトとリニアセンサが設置されている場合 である。このとき，(a)，(b)をともに満たしている，(ii) は車線 2 でリニアライトが, 車線 3 でリニアセンサがそ れぞれ設置されていない場合であるが，このとき，リニ アライトとリニアセンサの総数はそれぞれ $2(=n-1)$ で あり，すべての車線でそのいずれかが設置されているた め, この場合も (a), (b)をともに満たしている. しかし， (iii)の場合では, 車線 2 と車線 3 においてリニアライト が設置されておらず，その総数が $1(<n-1)$ となるため （a）を満たしていない，一方，(iv)の場合は，車線 2 にお いてリニアライトとリニアセンサがどちらも設置されて いないため (b)を満たしていない.したがって, (iii) と (iv) の場合はいかなる $f_{1}, f_{2}, g$ を用いても車両同士が 交差点で衝突する初期位置が存在する。

(1) 式より，本論文で扱うシステムは線形であるから, すべての車線にリニアライトとリニアセンサが設置され ている場合，これは，可制御可観測の車両が交差する問 題に相当する。したがって，(a) と（b)が満たされると き，不可制御な車両と不可観測な車両はそれぞれたかだ か 1 台であり, 定理 1 は自明のように思われるかもしれ ない.しかし，不可観測な車両が何台存在したとしても， 各リニアライトの制御アルゴリズムを別々に設定できる 場合，すなわち，(5)式において $g$ をリニアライトごと に異なるアルゴリズムにできる場合は，たとえば，通常 の交通信号機のように時分割で通行権を付与する以下の 制御アルゴリズムによって, 車両同士が衝突せずに交差 できる.

$$
g_{i}\left(t, x_{i}\right)= \begin{cases}v & \text { if } t \in[n k+(i-1), n k+i) \\ \left|x_{i}\right| & \text { otherwise }\end{cases}
$$

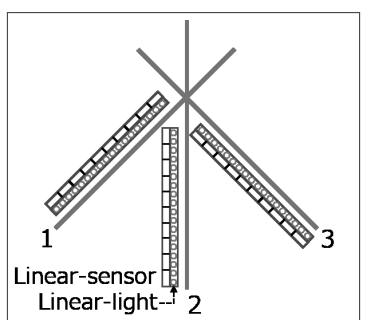

(i)

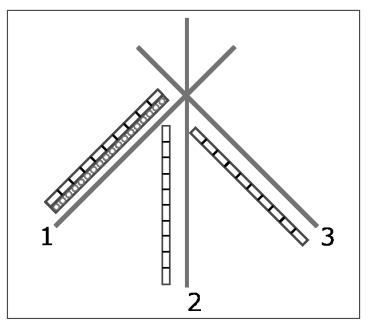

(iii)

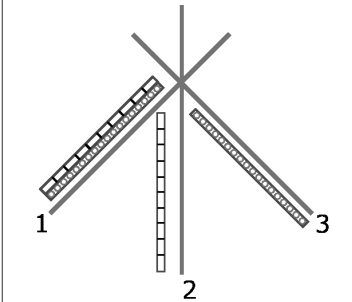

(ii)

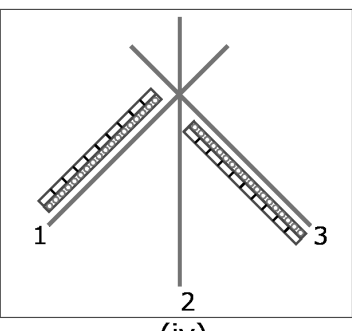

(iv)
Fig. 5 Examples for $n=3$

ここで, $k$ は任意の非負の整数, $v$ は任意に与えられた 正の実数である。つまり, 各リニアライトの制御アルゴ リズムを別々に設定できる場合は可観測な車両が何台存 在するかは，車両同士が衝突しないようなアルゴリズム が存在するための必要条件とはならない。一方, 定理で は各リニアライトの制御が同じであるという仮定のもと で, (a) と (b)が車両同士が衝突しないようなアルゴリズ ムが存在するための必要条件になることを示している。 この意味で, 定理 1 は不可観測な車両の存在から自明に 得られるものではない.

\section{4. 定理 1 の証明}

\section{1 準備}

上述した $\mathbf{I}_{s}, \mathbf{I}_{l}, \mathbf{I}_{n l}$ に加え， $\mathbf{I}_{n s} \subseteq\{1,2, \ldots, n\}$ をりニ アセンサが設置されていない車線のインデックス集合と する. ここで, $\mathbf{I}_{l} \cup \mathbf{I}_{n l}=\mathbf{I}$ かつ $\mathbf{I}_{s} \cup \mathbf{I}_{n s}=\mathbf{I}$ であること に注意する。

つづいて，Fig. 3 のような $n$ 本の一方通行の車線をあ るアルゴリズム $f_{1}, f_{2}, g$ によって車両が走行する場合 を考える. このとき, 以下の補題 1 3 3゙示される.

【補題 1】 $f_{1}, f_{2}, g$ が任意に与えられるものとする. このとき，ある車両 $i \in \mathbf{I}$, 時刻 $T \in[0, \infty)$ が存在し, 位 置が $x_{i}(T)<0$ となると仮定する。このとき，任意の時 刻 $t \in[T, \infty)$ において, 車両 $i$ のダイナミクスがもし $\dot{x}_{i}(t)=-x_{i}(t)$ となったとすれば, 任意の時刻 $t \in[T, \infty)$ において $x_{i}(t)<0$ となる.

（証明）時刻 $t \geq T$ における車両 $i$ の位置 $x_{i}(t)$ は以 下のように導かれる。

$$
x_{i}(t)=x_{i}(T) e^{-(t-T)}
$$

$e^{-(t-T)}>0$ より, $x_{i}(T)<0$ に対し, 任意の時刻 $t \in$ $[T, \infty)$ で $x_{i}(t)<0$ となる.

【補題 2】 $f_{1}, f_{2}, g$ が任意に与えられるものとする. 
このとき，ある車両 $i \in \mathbf{I}$, 時刻 $T \in[0, \infty)$ が存在し，位 置が $x_{i}(T)<0$ となると仮定する。このとき，任意の 時刻 $t \in[T, \infty)$ において, 車両 $i$ のダイナミクスがも し $\dot{x}_{i}(t)=v$ となったとすれば, $x_{i}\left(T^{\prime}\right)=0$ となる時刻 $T^{\prime} \in(T, \infty)$ が存在し, 任意の時刻 $t \in\left(T^{\prime}, \infty\right)$ において $x(t)>0$ となる。ただし， $v$ は任意に与えられた正の実 数である.

（証明）時刻 $t \geq T$ における車両 $i$ の位置 $x_{i}(t)$ は以 下のように導かれる。

$$
x_{i}(t)=x_{i}(T)+v(t-T)
$$

$v>0, x_{i}(T)<0$ より, $x_{i}\left(T^{\prime}\right)=0$ となる時刻 $T^{\prime}=$ $\frac{-x_{i}(T)}{v}+T$ が存在し, 任意の時刻 $t \in\left(T^{\prime}, \infty\right)$ で $x_{i}(t)>$ 0 となる.

【補題 3】 $f_{1}, f_{2}, g$ が任意に与えられるものとす る。このとき，ある車両 $i \in \mathbf{I}$ ，車両 $j \in \mathbf{I} \backslash\{i\} ，$ 時刻 $T \in[0, \infty)$ が存在し, $x_{i}(T)<0$ かつ任意の時刻 $t \in[T, \infty)$ において，車両 $i$ と車両 $j$ のダイナミクスがそれぞれ $\dot{x}_{i}(t)=v, \dot{x}_{j}(t)=v$ となると仮定する. このとき，もし $x_{i}(T) \neq x_{j}(T)$ ならば, 車両 $i$ と車両 $j$ は交差点で衝突 しない.

（証明）(9) 式より，任意の時刻 $t \geq T$ における車両 $i$ と車両 $j$ の位置の差は以下のように導かれる.

$$
x_{i}(t)-x_{j}(t)=x_{i}(T)-x_{j}(T)
$$

$x_{i}(T)-x_{j}(T)=\mathrm{const} \neq 0$ より,$x_{i}(T) \neq x_{j}(T)$ であれ ば，任意の時刻 $t \in[T, \infty)$ で $x_{i}(t) \neq x_{j}(t)$ であるため, 車両 $i$ と車両 $j$ が交差点で衝突しない.

\section{2 十分性の証明}

定理 1 の (a) と (b)が満たされるとき, ある $f_{1}, f_{2}, g$ が 存在して, 任意の初期位置 $x_{0 i} \in(-\infty, 0)(i=1,2, \ldots, n)$ に対し, 各車両が非零の速度を保ったまま他の車両と衝 突せずに交差点を通行することを証明する。

定理 1 の (a) と (b) が満たされる場合, リニアライト のみ，または，リニアセンサのみ設置されている車線は それぞれたかだか一つであり，リニアライトとリニアセ ンサがともに設置されていない車線は存在しない。 その ため, 十分性を示すためには, $n$ 本の車線のうち, 一つ がリニアライトのみ設置されている車線, 一つがリニア センサのみ設置されている車線, それ以外がリニアライ トとリニアセンサがともに設置されている車線の場合に ついて考えれば十分である。このとき，リニアライトの み設置されている車線を車線 $n$, リニアセンサのみ設置 されている車線を車線 1 としても一般性を失わないので, そのように仮定する。

このとき，たとえば以下のような $f_{1}, f_{2}, g$ を用いる.

$$
g\left(x_{i},\left[y_{j}(t)\right]_{j \in \mathbf{I}_{s} \backslash\{i\}}\right)= \begin{cases}v & \text { if } \operatorname{prio}\left(\boldsymbol{z}_{i}\right)=i \\ -x_{i} & \text { otherwise }\end{cases}
$$

$$
\begin{aligned}
f_{1}\left(r_{i}\left(t, x_{i}(t)\right)\right) & =r_{i}\left(t, x_{i}(t)\right) \\
f_{2}(t) & =v
\end{aligned}
$$

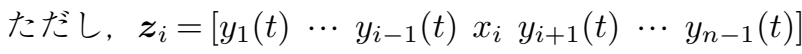
である。また, $v$ は任意に与えられた正の実数である.

このとき, $f_{1}, f_{2}, g$ に添字 $i$ が付かないという仮定 を満たしている。

$(11) \sim(13)$ 式のような $f_{1}, f_{2}, g$ を用いた場合, 以下 の補題 4,5 が成立する。

【補題 4】任意の車両 $i \in \mathbf{I}$ について, $x_{i}\left(T_{i}\right)<0$ を 満たし， かつ任意の時刻 $t \in\left[T_{i}, \infty\right)$ で $\dot{x}_{i}(t)=v$ となる ような $T_{i} \in[0, \infty)$ が存在する.

（証明）車両 1 について，車両 $1 \in \mathbf{I}_{n l}$ であることと， (1), (6), (13) 式より，任意の時刻 $t \in[0, \infty)$ における 車両 1 のダイナミクスは $\dot{x}_{1}(t)=v$ である.よって，車 両 1 について, $x_{1}\left(T_{1}\right)<0$ を満たし, かつ任意の時刻 $t \in\left[T_{1}, \infty\right)$ で $\dot{x}_{1}(t)=v$ となるような $T_{1} \in[0, \infty)$ が存 在する.

車両 $i \in \mathbf{I} \backslash\{1, n\}$ について考える。ある時刻におい て，車両 $n$ を除く非正の領域内に位置する車両のう ち, 位置が唯一最大，または，位置が最大かつそのう ち車両番号が最小である車両 $j$ の位置が $-v \leq x_{j}(t)$ と なったとする。このとき， $\mathbf{I}_{s}=\{1, \ldots, n-1\}$ であるこ とと $(2)$ 式より, $\operatorname{prio}\left(\boldsymbol{z}_{j}(t)\right)=j$ が成り立つ. ただし,

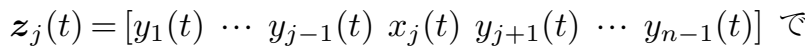
ある。(1), (3), (4), (11), (12) 式より, 車両 $j$ のダイナ ミクスは $\dot{x}_{j}(t)=v$ である。 また，車両 $k \in \mathbf{I} \backslash\{1, j, n\}$ について $\operatorname{prio}\left(\boldsymbol{z}_{k}(t)\right) \neq k$ であり, $\dot{x}_{k}(t)=-x_{k}(t)$ とな る. よって, 車両 $j$ と車両 $k$ との位置の大小関係は $x_{j}(t)=0$ となるまで変わらず, その間, $\operatorname{prio}\left(\boldsymbol{z}_{j}(t)\right)=j$ が成り立ち， $\dot{x}_{j}(t)=v$ である. $x_{j}(t)>0$ となると， $(1)$ $(3),(4),(13)$ 式より, 車両 $j$ のダイナミクスは $\dot{x}_{j}(t)=v$ である。その後も，関数 prioの性質より，任意の車両 $i \in \mathbf{I} \backslash\{n\}$ が $x_{i}(t)>0$ となるまで $\operatorname{prio}\left(\boldsymbol{z}_{i}(t)\right)=i$ とな る車両 $i \in \mathbf{I} \backslash\{n\}$ は唯一存在する。 よって, 任意の車両 $i \in \mathbf{I} \backslash\{1, n\}$ について， $x_{i}\left(T_{i}\right)<0$ を満たし，かつ任意 の時刻 $t \in\left[T_{i}, \infty\right)$ で $\dot{x}_{i}(t)=v$ となるような $T_{i} \in[0, \infty)$ が存在する.

車両 $n$ について, 関数 prioの性質より, 非正の領域 内の車両のうち, 車両 $n$ の位置が唯一最大であるとき, $\operatorname{prio}\left(\boldsymbol{z}_{n}(t)\right)=n$ である. このとき，(1), (3), (4), (11), $(12)$ 式より, 車両 $n$ のダイナミクスは $\dot{x}_{n}(t)=v$ である. 任意の車両 $i \in \mathbf{I} \backslash\{n\}$ について, 任意の時刻 $t \in\left[T_{i}, \infty\right)$ で, $\dot{x}_{i}(t)=v$ となるような $T_{i} \in[0, \infty)$ が存在すること は示されているため, 非正の領域内の車両のうち, 車 両 $n$ の位置が唯一最大となる時刻は必ず存在する。よっ て, 車両 $i \in \mathbf{I} \backslash\{1, n\}$ の場合と同様に，車両 $n$ につい て, $x_{n}\left(T_{n}\right)<0$ を満たし，かつ任意の時刻 $t \in\left[T_{n}, \infty\right)$ で, $\dot{x}_{n}(t)=v$ となるような $T_{n} \in[0, \infty)$ が存在する.

【補題 5】任意の車両 $i \in \mathbf{I} に つ い て ， T_{i}$ が存在し 
て，任意の時刻 $t \in\left[T_{i}, \infty\right)$ で $\dot{x}_{i}(t)=v$ となると仮定す

る.このとき, $T_{j} \leq T_{i}$ である任意の車両 $i \in \mathbf{I}, j \in \mathbf{I} \backslash\{i\}$ について $x_{i}\left(T_{i}\right) \neq x_{j}\left(T_{i}\right)$ となる.

（証明） $\mathbf{I}_{l}=\{2, \ldots, n\}$ であることと，(1)，(3)，(4)， $(11),(12)$ 式より，位置 $x_{i}(t) \leq 0$ である車両 $i \in \mathbf{I} \backslash\{1\}$ のダイナミクスが $\dot{x}_{i}(t)=v$ となるのは, $\operatorname{prio}\left(\boldsymbol{z}_{i}(t)\right)=i$ のときのみである.

任意の車両 $i \in \mathbf{I} \backslash\{1, n\}$ について $\operatorname{prio}\left(\boldsymbol{z}_{i}(t)\right)=i$ が 成り立つとき，関数 prio の性質より，任意の車両 $j \in$ $\mathbf{I} \backslash\{1, i, n\}$ について $\operatorname{prio}\left(\boldsymbol{z}_{j}(t)\right) \neq j$ である。すなわ ち， $x_{i}(t) \leq 0$ である車両 $i$ について $\operatorname{prio}\left(\boldsymbol{z}_{i}(t)\right)=i$ が 成り立ち，ダイナミクスが $\dot{x}_{i}(t)=v$ となるとき，車 両 $j$ のダイナミクスが $\dot{x}_{j}(t)=v$ ならば, $x_{j}(t)>0$ であるといえる。よって， $T_{i} \geq T_{j}$ である任意の車両 $i \in \mathbf{I} \backslash\{1, n\}, j \in \mathbf{I} \backslash\{1, i, n\}$ について,$x_{i}\left(T_{i}\right) \neq x_{j}\left(T_{i}\right)$ となる。

また，関数 prio の性質より，車両 $i \in \mathbf{I} \backslash\{1, n\}$ につい て $\operatorname{prio}\left(\boldsymbol{z}_{i}(t)\right)=i$ となることは, $x_{1}(t) \neq x_{i}(t)$ であるこ とを意味する，よって，車両 1 と任意の車両 $i \in \mathbf{I} \backslash\{1, n\}$ について, $T_{1} \geq T_{i}$ のとき $x_{1}\left(T_{1}\right) \neq x_{i}\left(T_{1}\right), T_{1}<T_{i}$ の とき $x_{1}\left(T_{i}\right) \neq x_{i}\left(T_{i}\right)$ となる.

車両 $n$ について, 関数 prioの性質より, $\operatorname{prio}\left(z_{n}(t)\right)=$ $n$ となるとき, 車両 $n$ の位置が非正の領域内の車両の うち唯一最大となる。すなわち，このとき任意の車両 $i \in \mathbf{I} \backslash\{n\}$ に対し， $x_{n}(t) \neq x_{i}(t)$ である。 よって，任意 の車両 $i \in \mathbf{I} \backslash\{n\}$ と車両 $n$ について, $T_{i} \geq T_{n}$ のとき $x_{i}\left(T_{i}\right) \neq x_{n}\left(T_{i}\right), \quad T_{i}<T_{n}$ のとき $x_{i}\left(T_{n}\right) \neq x_{n}\left(T_{n}\right)$ とな る.

(1), (3), (4), (11) (13) 式より, 各車両のダイナミク スは $\dot{x}_{i}(t)=v$ もしくは $\dot{x}_{i}(t)=-x_{i}(t)$ が交差点を通行 する時刻までの時間区間で繰り返し出現し，長さは非零 である。

任意の車両 $i \in \mathbf{I}$ について, 補題 4 より, ある $T_{i 1}$ が 存在し，任意の時刻 $t \in\left[T_{i 1}, \infty\right)$ で $\dot{x}_{i}(t)=v$ となる。 ま た，補題 2,4 より，ある $T_{i 2}$ が存在し， $x_{i}\left(T_{i 2}\right)=0$ と なる。すすわち，任意の時刻 $t \in\left[T_{i 1}, T_{i 2}\right]$ で $\dot{x}_{i}(t)=v$ となる

任意の車両 $j \in \mathbf{I} \backslash\{i\}$ について， ある $T_{j 1}$ が存在し， 任意の時刻 $t \in\left[T_{j 1}, T_{i 2}\right]$ で車両 $j$ のダイナミクスは変わ らない.

もし，車両 $j$ のダイナミクスがその区間上で $\dot{x}_{j}(t)=$ $-x_{j}(t)$ ならば補題 $\mathbf{1}$ より車両 $i$ と交差点で衝突しない. $\dot{x}_{j}(t)=v$ ならば補題 $\mathbf{3}, \mathbf{5}$ より車両 $i$ と交差点で衝突し ない.

以上により，定理 1 の十分性が示された。

\section{3 必要性の証明}

定理 1 の (a) と (b)のいずれかが満たされないとき, つぎのいずれかの車両の組が存在する。

(i) $(i, j) \in\left(\mathbf{I}_{l} \cap \mathbf{I}_{n s}\right) \times\left(\left(\mathbf{I}_{l} \cap \mathbf{I}_{n s}\right) \backslash\{i\}\right)$ (ii) $(i, j) \in\left(\mathbf{I}_{n l} \cap \mathbf{I}_{s}\right) \times\left(\left(\mathbf{I}_{n l} \cap \mathbf{I}_{s}\right) \backslash\{i\}\right)$

(iii) $(i, j) \in\left(\mathbf{I}_{n l} \cap \mathbf{I}_{n s}\right) \times(\mathbf{I} \backslash\{i\})$

それぞれの場合について，いかなる $f_{1}, f_{2}, g$ を与えて も車両 $i$ と車両 $j$ が交差点で衝突する，もしくは，少 なくとも一方が交差点を通行しないような初期位置の組 $\left(x_{0 i}, x_{0 j}\right) \in(-\infty, 0)^{2}$ が存在することを示す.

任意の $f_{1}, f_{2}, g$ の組合せは，それらが与えられたと き, 任意の初期位置に対し車両 $i$ と車両 $j$ がともに交差 点を通行する場合と，どちらか一方が交差点を通行しな いような初期位置が存在する場合の 2 通りに分けられる。

よって，任意の初期位置に対し車両 $i$ と車両 $j$ がとも に交差点を通行するような $f_{1}, f_{2}, g$ を与えたとき, 車 両 $i$ と車両 $j$ が交差点で衝突するような初期位置の組が 存在することを示せばよい．

\subsection{1（i)について}

車両 $i \in \mathbf{I}_{l}$, 車両 $j \in \mathbf{I}_{l}$ であるから，(5) 式より，任意 の時刻 $t \in[0, \infty)$ に扔ける車線 $i$ と車線 $j$ のリニアライ 卜の指令值はそれぞれ以下のように表される。

$$
\begin{aligned}
r_{i}\left(t, x_{i}\right) & =g\left(x_{i},\left[y_{k}(t)\right]_{k \in \mathbf{I}_{s}}\right) \\
r_{j}\left(t, x_{j}\right) & =g\left(x_{j},\left[y_{k}(t)\right]_{k \in \mathbf{I}_{s}}\right)
\end{aligned}
$$

このとき，位置 $x_{i}(t), x_{j}(t)$ はそれぞれ $(1),(4)$ 式より $x_{i}(t) \leq 0, x_{j}(t) \leq 0$ において以下のように導かれる.

$$
\begin{aligned}
& x_{i}(t)=x_{0 i}+\int_{0}^{t} f_{1}\left(r_{i}\left(\tau, x_{i}(\tau)\right)\right) d \tau \\
& x_{j}(t)=x_{0 j}+\int_{0}^{t} f_{1}\left(r_{j}\left(\tau, x_{j}(\tau)\right)\right) d \tau
\end{aligned}
$$

車両 $i \in \mathbf{I}_{n s}$, 車両 $j \in \mathbf{I}_{n s}$ であるから, $x_{i}(t), x_{j}(t)$ はそ れぞれ $x_{j}(t), x_{i}(t)$ に依存しない関数である。したがっ て, ある $f_{1}, f_{2}, g$ が与えられ, ある初期位置に対し, 車 両 $i$ について時刻 $T \in(0, \infty)$ で $x_{i}(T)=0$ が成り立つ とき, 車両 $j$ の初期位置 $x_{0 j}=-\int_{0}^{T} f_{1}\left(r_{j}\left(\tau, x_{j}(\tau)\right)\right) d \tau$ が存在し, $x_{j}(T)=0$ となるから, 車両 $i$ と車両 $j$ が交 差点で衝突するような初期位置の組が存在する.

\subsection{2（ii）について}

車両 $i \in \mathbf{I}_{n l}$, 車両 $j \in \mathbf{I}_{n l}$ であるから，(1)，(6) 式よ $\eta$, 任意の時刻 $t \in[0, \infty)$ における車両 $i$ と車両 $j$ の夕゙ イナミクスはともに $f_{2}(t)$ である. よって, 位置 $x_{i}(t)$, $x_{j}(t)$ はそれぞれ以下のように導かれる.

$$
\begin{aligned}
& x_{i}(t)=x_{0 i}+\int_{0}^{t} f_{2}(\tau) d \tau \\
& x_{j}(t)=x_{0 j}+\int_{0}^{t} f_{2}(\tau) d \tau
\end{aligned}
$$

よって， $x_{0 i}=x_{0 j}$ を満たすとき，任意の時刻 $t \in[0, \infty)$ で $x_{i}(t)=x_{j}(t)$ である. したがって，ある $f_{1}, f_{2}, g$ が 与えられ, ある初期位置に対し, 車両 $i$ について時刻 $T \in(0, \infty)$ で $x_{i}(T)=0$ が成り立つとき, 車両 $j$ の初期 位置 $x_{0 j}=x_{0 i}$ が存在し, $x_{j}(T)=0$ となるから, 車両 $i$ 
と車両 $j$ が交差点で衝突するような初期位置の組が存在 する.

\subsection{3 (iii) について}

車両 $j \in \mathbf{I}_{n l}$ のとき，(ii)の場合と同様に考えられるた め, ここでは車両 $j \in \mathbf{I}_{l}$ とする．このとき，(5)式より， 時刻 $t$ に扔ける車線 $j$ のリニアライトの指令值は以下の ように表される。

$$
r_{j}\left(t, x_{j}\right)=g\left(x_{j},\left[y_{k}(t)\right]_{k \in \mathbf{I}_{s} \backslash\{j\}}\right)
$$

このとき，車両 $i \in \mathbf{I}_{n l}$ であることと，(1)，(4) 式より， 任意の時刻 $t \in[0, \infty)$ における位置 $x_{i}(t), x_{j}(t)$ はそ れぞれ $x_{i}(t) \leq 0, x_{j}(t) \leq 0$ において以下のように導か れる。

$$
\begin{aligned}
& x_{i}(t)=x_{0 i}+\int_{0}^{t} f_{2}(\tau) d \tau \\
& x_{j}(t)=x_{0 j}+\int_{0}^{t} f_{1}\left(r_{j}\left(\tau, x_{j}(\tau)\right)\right) d \tau
\end{aligned}
$$

車両 $i \in \mathbf{I}_{n s}$ であるから， $x_{j}(t)$ は $x_{i}(t)$ に依存しない. よって，ある $f_{1}, f_{2}, g$ が与えられ，ある初期位置に対 し, 車両 $j$ について時刻 $T \in(0, \infty)$ で $x_{j}(T)=0$ が成 り立つとき, 車両 $i$ の初期位置 $x_{0 i}=-\int_{0}^{T} f_{2}(\tau) d \tau$ が 存在し, $x_{i}(T)=0$ となるから, 車両 $i$ と車両 $j$ が交差 点で衝突するような初期位置の組が存在する.

以上により, 定理 1 の必要性が示された。

\section{5. おわりに}

本研究では, $n$ 本の一方通行路が交わる交差点におい て，車両が安全に交差するためのリニア信号機の最小構 成を考えた。その結果，リニア信号機を構成するリニア ライトとリニアセンサがそれぞれ $(n-1)$ 個必要であり， また，それらは，リニアライトとリニアセンサがいずれ も備えられない車線が存在しないように配置する必要が あることを明らかにした。本成果は，リニア信号機を用 いた交通システムの設計や信頼性解析の基礎的結果にな るものと考えられる。

\section{参考文 献}

[1] 吉川, 丸田, 東, 杉江：リニア信号機による自動運転ネッ トワーク；第 4 回制御部門マルチシンポジウム， 2C3-1 (2017)

[2] 総務省 : 平成 27 年版情報通信白書, ICT の過去・現在・ 未来 (2015)

[3] 尾崎, 長尾：交差点エリアの自動走行制御による交通事 故防止システム ; 情報処理学会第 70 回全国大会 (2008)

[4] 金森, 高橋, 伊藤：ドライバーの経路選択行動を考慮 した予見的情報に基づく経路割当戦略に関する研究; 電子情報通信学会論文誌 D, Vol. J96-D, No. 12, pp. 3009-3018 (2013)

[5] 太田, 米田, 能登：自動運転のための分散型交通管制シ ステムの提案 ; 情報処理学会第 77 回全国大会 (2015)

\section{著 者略歴}

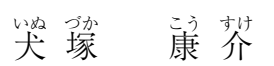

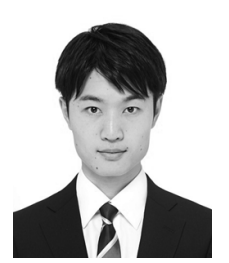

2018 年 3 月名古屋大学工学部機械航空 工学科卒業, 同年 4 月名古屋大学大学院工 学研究科機械システム工学専攻博士前期課 程に入学し現在に至る. マルチエージェン トシステムの研究に従事.

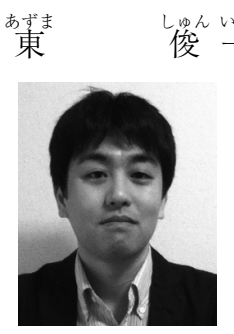

(正会員)

2004 年 9 月東京工業大学大学院情報理 工学研究科博士後期課程修了. 同年 4 月よ り日本学術振興会特別研究員, 2005 年 9 月京都大学大学院情報学研究科助手, 2011 年 6 月同准教授, 2017 年 4 月名古屋大学 大学院工学研究科教授となり現在に至る. ハイブリッドシステムやネットワークシステムの研究に従事. 博士 (工学) 。2005 年, 2008 年, 2014 年, 2016 年計測自 動制御学会論文賞, 2011 年度同学会制御部門パイオニア賞, 2016 年同学会著述賞, 2014 年システム制御情報学会論文賞 などを受賞. IEEE, 計測自動制御学会, 電子情報通信学会, 日本機械学会などの会員.

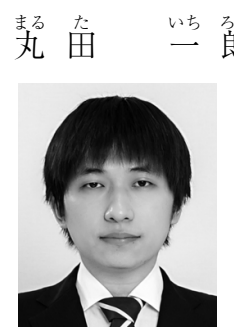

(正会員)

2011 年 3 月京都大学大学院情報学研究 科システム科学専攻博士後期課程修了。同 年 4 月から 12 月まで日本学術振興会特別 研究員 PD（慶應義塾大学訪問研究員）. 2012 年 1 月京都大学大学院情報学研究科 特定助教, 2013 年 7 月同助教, 2017 年 5 月から京都大学大学院工学研究科講師となり現在に至る. 制 御理論とシステム同定の研究に従事. 博士 (情報学). 計測 自動制御学会などの会員.

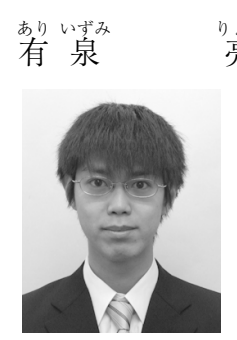

”兑 (正会員)

2015 年 3 月京都大学大学院工学研究科 博士課程修了。 2014 年 3 月から 2015 年 9 月まで日本学術振興会特別研究員. 2015 年 10 月より名古屋大学大学院工学研究科 助教となり現在に至る、ロボット制御，統 計的最適化の研究に従事. IEEE, 日本口 ボット学会, 日本機械学会, 計測自動制御学会などの会員. 


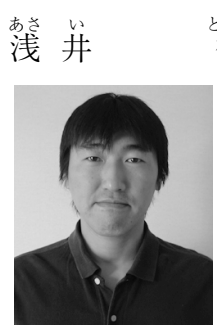

徹 (正会員)

1996 年 3 月東京工業大学大学院理工学

研究科制御工学専攻修了. 同年 1 月日本学

術振興会特別研究員. 1999 年 3 月大阪大

学大学院工学研究科助手, 2002 年 4 月同

研究科講師, 2005 年 4 月同研究科助教授,

2007 年 4 月同研究科准教授, 2015 年 4 月

名古屋大学大学院工学研究科准教授となり, 現在に至る. 博

士 (工学) . IEEE, 日本鉄鋼協会の会員. 